\title{
Litterfall and Nutrient Returns in the Rainforest of Southwestern Cameroon: Some Implications for Tropical Forest Productivity
}

\author{
Mary E. Ngaiwi ${ }^{1,2}$, Ernest L. Molua ${ }^{1,2}$ \& Andrew E. Egbe ${ }^{1}$ \\ ${ }^{1}$ Faculty of Agriculture and Veterinary Medicine, University of Buea, P.O. Box 63 Buea, Cameroon \\ ${ }^{2}$ Centre for Independent Development Research, P.O. Box 58 Buea, SWR, Cameroon \\ Correspondence: Mary E. Ngaiwi, Faculty of Agriculture and Veterinary Medicine, University of Buea, P.O. Box \\ 63 Buea, Cameroon. Tel: 237-683-733-811. E-mail: maryngaiwi@gmail.com
}

Received: May15, 2018

doi:10.5539/enrr.v8n3p25
Accepted: June 9, 2018

Online Published: June 18, 2018

\begin{abstract}
Understanding litterfall and macronutrients in the rainforest ecosystem gives baseline information on nutrient dynamics. Litterfall and macronutrients return were studied for 12 months from November 2011 to October 2012 in a 50 ha plot in the Takamanda National Park, South-western Cameroon. This study evaluates the pattern and quantity of litterfall, with implications for forest productivity. It thus assesses the macronutrient concentrations, nutrient inputs into the surface soil, nutrient retranslocation by some key tree species and some physicochemical properties of the soil in the study site. Litter traps where placed randomly in the study plot. Litter was collected every fortnight sorted and air-dried after which they were oven dried at $70^{\circ} \mathrm{C}$ to constant weight. Soils were sampled from three flanks at depths of $0-10 \mathrm{~cm}, 10-20 \mathrm{~cm}$ and $20-30 \mathrm{~cm}$. Percentage retranslocation or accumulation before leaf fall was calculated from freshly fallen litter and mature green leaf. Total annual litterfall was $5.46 \mathrm{t} / \mathrm{ha} / \mathrm{yr}$ and this varied with the seasons. Leaf litter contributed $90.9 \%$ of total litterfall. The concentration of $\mathrm{N}$ and $\mathrm{Ca}$ was higher than other nutrient elements $\mathrm{Mg}, \mathrm{K}, \mathrm{P}$ in all litter fragments. Nitrogen had the highest total nutrient input with the following pattern $\mathrm{N}>\mathrm{Ca}>\mathrm{K}>\mathrm{Mg}>\mathrm{P}(85.36 \mathrm{~kg} / \mathrm{ha} / \mathrm{yr}>56.71 \mathrm{~kg} / \mathrm{ha} / \mathrm{yr}>23.1$ $\mathrm{kg} / \mathrm{ha} / \mathrm{yr}>17.32 \mathrm{~kg} / \mathrm{ha} / \mathrm{yr}>4.27 \mathrm{~kg} / \mathrm{ha} / \mathrm{yr}$ ) respectively.Pterocarpus soyauxii had the highest retranslocation percentages for all the macronutrients studied compared to Afziliabipidensis and Terminalia ivorensis. It was observed that Terminalia ivorensis could be a good nutrient recycler that could be used to improve on degraded soils. It was however observed that $\mathrm{Ca}$ and $\mathrm{Mg}$ tend to accumulate in leaf litter for all the three species.
\end{abstract}

Keywords: Rainforests, Pterocarpus soyauxii, Terminalia ivorensis, Litterfall, Productivity, Nutrient returns

\section{Introduction}

Forest productivity relies on the quantity and quality of litter which influences nutrient cycling in the ecosystem (Eguakun\& Job, 2018). The amount of litter produced is the major indicator of primary productivity because as litter quantity increases nutrient content available for plant growth also increases (Eguakun \& Job, 2018). Litterfall is the primary source of carbon and nutrients that determine soil fertility in forest ecosystems (Changkun et al., 2017). Litter production is a major factor that determines the nutrient return of forest ecosystems (Bigelow \& Canham, 2015) and its components affect the efficiency of material circulation (Wang et al.,2016) the rate of nutrient return and litter decomposition through litter quality and dynamics (Lidman et al.,2017). Litterfall is a useful indicator of productivity and the establishment of ecological functions showing that, in terms of productivity, riparian forest seems to be sustainable (Londe et al., 2016). Thus, Litter is particularly important in forests that grow on infertile soils, where the amount of nutrients entering into the soil through atmospheric deposition or weathering, is disproportionately small compared to the amount of nutrients contained in the above- ground litterfall (Van Dam, 2001). Litterfall, with its associated flux of nutrients (from litter to soil and back to plants), is one of the basic processes of biogeochemical cycles in terrestrial ecosystems. In the biogeochemical cycles of organic matter and mineral elements, litterfall plays an important role in the relationships among soil, vegetation and surrounding environment, constituting one of the essential ecological phenomena in the woodland ecosystems (Vitousek et al., 1995). A forest constitutes an open system with chemical elements entering in and out of it, or moving internally within it.The vegetations act as nutrient stores in the ecosystem (Vitousek et al., 1995). These nutrients later move into the soil by means of falling leaves, twigs, reproductive structures, through fall, stem flow etc (Higuera \& Martinez, 2006). Litterfall reflects forest 
productivity and is an important pathway of nutrient cycling in forests (Vitousek 1984), and both the quantity and quality of litterfall impact on nutrient cycling (Bray \& Gorham 1964). The amount of litterfall and nutrient inputs is also a potential key to describing any change that might occur in a forest when it is disturbed, In general, litterfall fractions have been used to evaluate site productivity, decomposition rate and to estimate nutrient return to the soil (Guendehou et al., 2014) Thus this paper seeks to estimate the contribution of litter production to nutrient input in the Tropical rainforest of Takamanda. The remainder of the paper is structured as follows: section 2 presents the materials and methods, section 3 discusses the results while section 4 concludes the paper.

\section{Materials and Methods}

\subsection{Site Description}

The study was carried out in the rainforest of Takamanda National Park, Manyu Division, South West Region of Cameroon. Precisely between geographical coordinates: $05^{\circ} 59^{\prime}-06^{\circ} 21^{\prime} \mathrm{N}$ and $09^{\circ} 11-09^{\circ} 30^{\prime} \mathrm{E}$. The rainforest is situated at the northern corner of the South West Region of Cameroon and partly in the northeast of the extensive Cross River Valley along the eastern border of Nigeria.The region has two distinct seasons with most rainfall occurring from July to October with the peaks in September and August. From November to February, the climate is mainly dry. Some months usually December, January, February may receive little or no rain at all.The monthly maximum temperature is about $33.4^{\circ} \mathrm{C}$ and minimum temperatures of $26.4^{\circ} \mathrm{C}$ with mean annual temperature of $26.48^{\circ} \mathrm{C}$ (Figure 1). This Park is a hotspot for Biodiversity conservation. Gorillas from this region are geographically and morphologically distinct from other gorillas (Sarmiento \& Oates 2000), and they are now recognized as the fourth gorilla sub species the Cross River gorilla and classified as critically endangered (IUCN, 2000). The forests of Takamanda are also important for a great diversity of birds as recognized by Birdlife International when it designated the Reserve an important Bird Area. Reptile diversity is equally impressive, Butterflies (111 species, Sunderland-Groves et al., 2003) and dragonflies (67 species) have high levels of diversity. Both groups are important indicators of forest change. Likewise, 54 species of fish were registered, many of which provide an important protein source to local communities (Sunderland-Groves et al., 2003). Flora also proves to be extremely rich with more than 950 species of plants registered over the course of the present surveys. Of these, 351 species were trees with diameters greater than $10 \mathrm{~cm}$ (Sunderland et al., 2003).

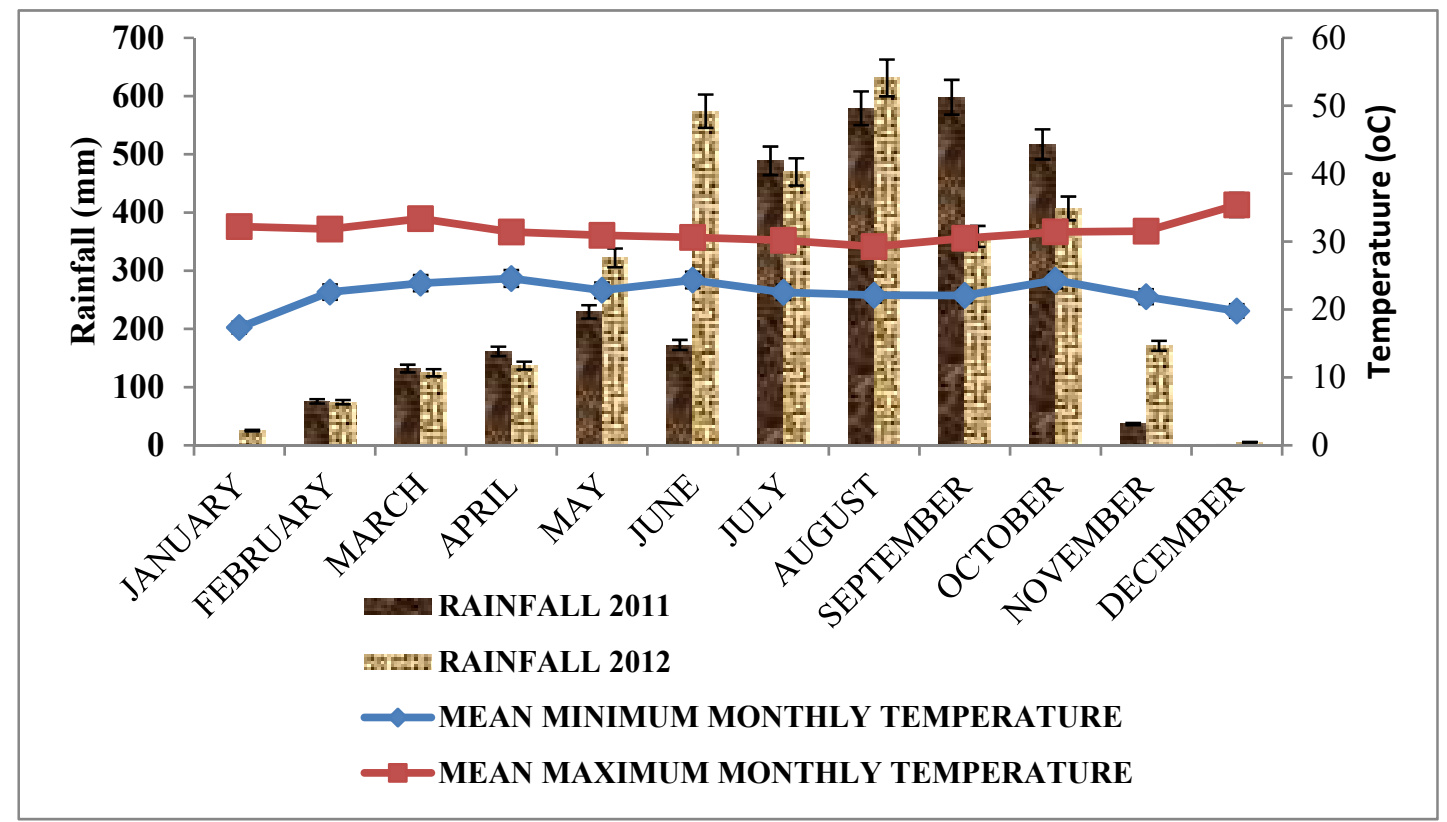

Figure 1. Temperature and rainfall patterns of the study area (constructed by author)

\subsection{Litter Collection}

One hundred litterfall traps of $2 \times 2 \mathrm{~m}$ made of mesh bags with mesh size of $0.5 \times 0.5 \mathrm{~mm}$ and $0.2 \mathrm{~m}$ deep were placed randomly $50 \mathrm{~cm}$ aboveground in a 50 ha Takamanda Forest Dynamic Plot (TFDP). And the litter was collected at fortnight intervals from November 2011 to October 2012 . The collected litter at each time was air 
dried, bulked to monthly samples, sorted into leaves, twigs $(\leq 2 \mathrm{~cm})$ and reproductive structures and oven dried at $70^{\circ} \mathrm{C}$ to constant weight. After oven drying, the samples were allowed to cool and later weighed with a sensitive balance (Ohaus SP2001 Scout TM Pro). Litterfall per month subsamples (50 g-500 g) were taken from each representative plant part for chemical analysis.

\subsection{Retranslocation}

Fresh mature green leaves were collected from well-illuminated positions of the crown from the main canopy of the following tree species; Afzeliabipidensis, Pterocarpus soyauxii, Terminalia ivorensis. This species were selected per their important value index.A tree climber used a pruner mounted on a $7.5 \mathrm{~m}$ pole and collected fresh green leaves.They were labelled and stored in polythene bags immediately after collection and later air-dried in the field.Freshly fallen senescence leaf litter of these selected species were collected by trapping onto three large plastic sheets 2 by $2 \mathrm{~m}$ placed under each of the selected trees as described by Chuyong et al. (2000).The freshness of the leaf was determined by visual observation of the abscission layer at the end of the petiole.The leaf samples were labelled and taken to the life science laboratory of the University of Buea, faculty of science. All the leaf samples (green leaves, fresh fallen brown leaves) were oven-dried at $70^{\circ} \mathrm{C}$ for 72 hours and later milled to fine powder.All milled leaf samples were taken to the International Institute of Tropical Agriculture (IITA) Yaounde for routine chemical analysis.The percentages of $\mathrm{N}, \mathrm{Ca}, \mathrm{Mg}, \mathrm{K}$ and $\mathrm{P}$ retranslocated or accumulated before leaf fall in the selected tree species were calculated from the freshly fallen litter and mature green leaf concentrations expressed per unit dry weight and per unit weight of calcium concentration in the leaf litter, as: Retranslocation $(\%)=100[1-(\mathrm{X} / \mathrm{Y})]$; Where $\mathrm{X}=$ (nutrient concentration in fallen brown leaves)/ $(\mathrm{Ca}$ concentration in fallen brown leaves), $\mathrm{Y}=$ (nutrient concentration in mature green leaves)/ (Ca concentration in mature green leaves) (Chuyong et al., 2000).

\subsection{Chemical Analysis of Plant Samples}

The milled plant samples were analysed as follows; basic cations $\mathrm{Mg}$, $\mathrm{Ca}$ and $\mathrm{K}$ were extracted by dry ash in a muffle furnace at $500^{\circ} \mathrm{C}$, diluted using a dilute acid mix of $\mathrm{HCl} / \mathrm{HNO}_{3}$ and analyzed using the atomic absorption spectrophotometer (Benton \& Vernon, 1990). Phosphorus was extracted by first carrying out dry ash, and later analyzed using Murphy Riley reagent, and the absorbance read colorimetrically. Total nitrogen was determined from a wet acid digest (Buondonnoet al., 1995) and later analyzed using colorimetric analysis (Anderson \& Ingram, 1993).

\subsection{Statistical Analysis}

Analyses of Variance were carried out on the data using GENSTAT statistical package to evaluate the amount of litter production and nutrient input in the study site. Comparisons were done using the least significance difference (LSD) of the means. In order to qualify the relationship between litterfall and rainfall and litterfall with temperature, we correlated the mass of litterfall and rainfall also with temperature to get the one that impacts litter production negatively or positively. Macronutrients concentrations in different litterfall components were correlated between their monthly concentrations and Biomass using Pairwise correlations.

\section{Results and Discussion}

\subsection{Pattern of Litterfall}

Total annual litter production was 5.46t/ha/yr, with peak production in February. Leaf litter production occurred throughout the months of study but with some variations. Leaf litterfall increased from January to February, with highest peak in February ( $549 \mathrm{Kg} / \mathrm{ha}$ ) (Figure 2). There was then a sharp decrease to March from which a steady pattern was maintained to June. An increase occurred from June to July then decreased to October (305.11 $\mathrm{kg} / \mathrm{ha}$ ), which had the least leaf litterfall. Twig litter was also observed throughout the study period. It decreased from the highest production in January $(74 \mathrm{Kg} / \mathrm{ha}$ ) with an increase in June, experiencing its least production in July $(13 \mathrm{Kg} / \mathrm{ha})$. Reproductive parts were the lowest fraction of litter. The highest peak of reproductive litter was in January $(10 \mathrm{~kg} / \mathrm{ha})$ with the least production in December $(2 \mathrm{~kg} / \mathrm{ha})$. 


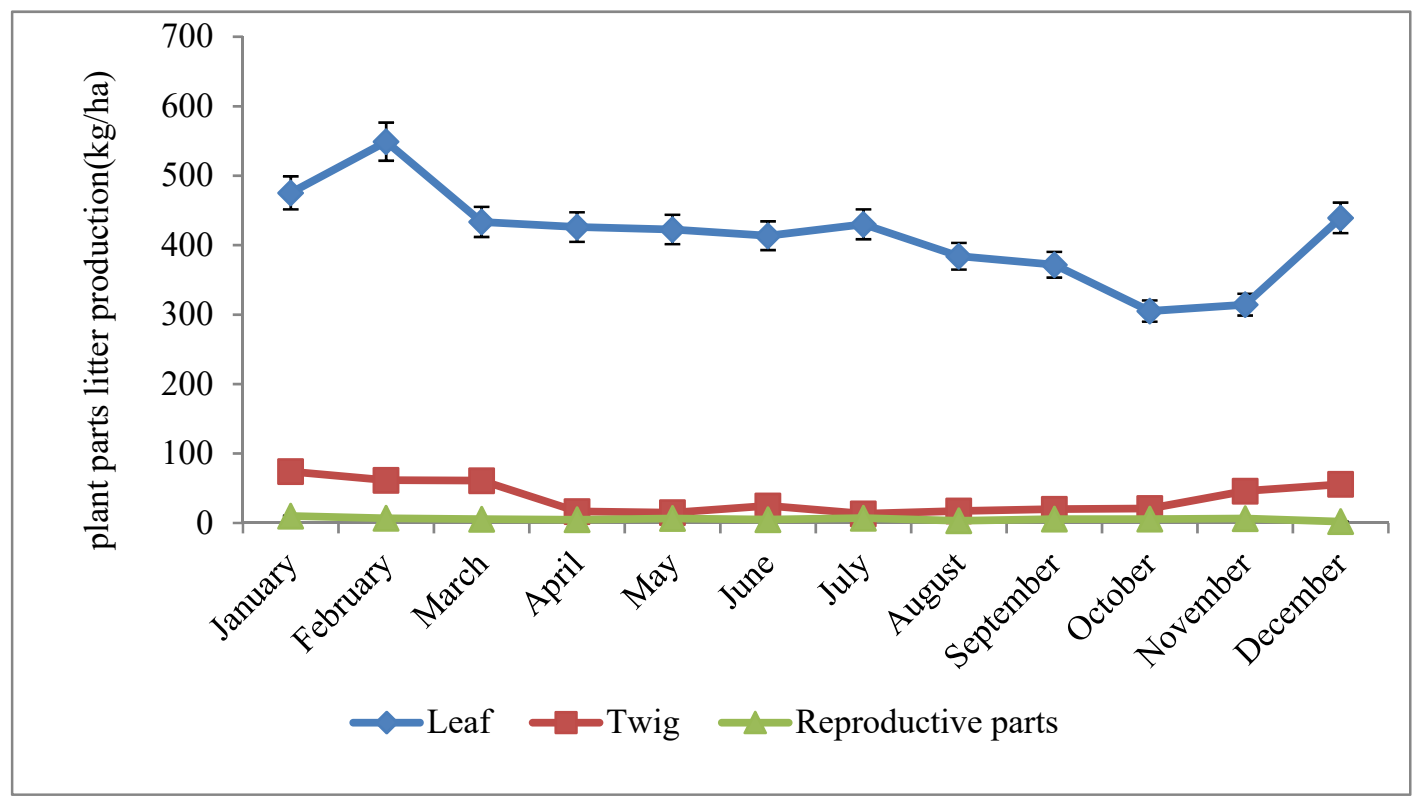

Figure 2. Monthly litterfall by the various litter fragments

\subsection{Monthly Variation of Macronutrients Concentrations}

$\mathrm{N}$ and $\mathrm{Ca}$ were significantly higher than that of $\mathrm{K}, \mathrm{P}$ and $\mathrm{Mg}$ in the leaves, with nitrogen having the highest concentrations. The nutrient concentrations pattern was as follows $\mathrm{N}>\mathrm{Ca}>\mathrm{K}>\mathrm{Mg}>\mathrm{P}$. The concentration of nitrogen decreased from January to December with peak concentrations in March $(1.76 \mathrm{~g} / \mathrm{kg})$ and least in February $(1.3 \mathrm{~g} / \mathrm{kg})$. Calcium concentration decreased from January to May then increased to the highest concentration November $(1.9 \mathrm{~g} / \mathrm{Kg})$. Phosphorus was highest in May and October $(0.1 \mathrm{~g} / \mathrm{kg})$ (Figure 3) and least in June and July with concentrations of $0.6 \mathrm{~g} / \mathrm{kg}$.

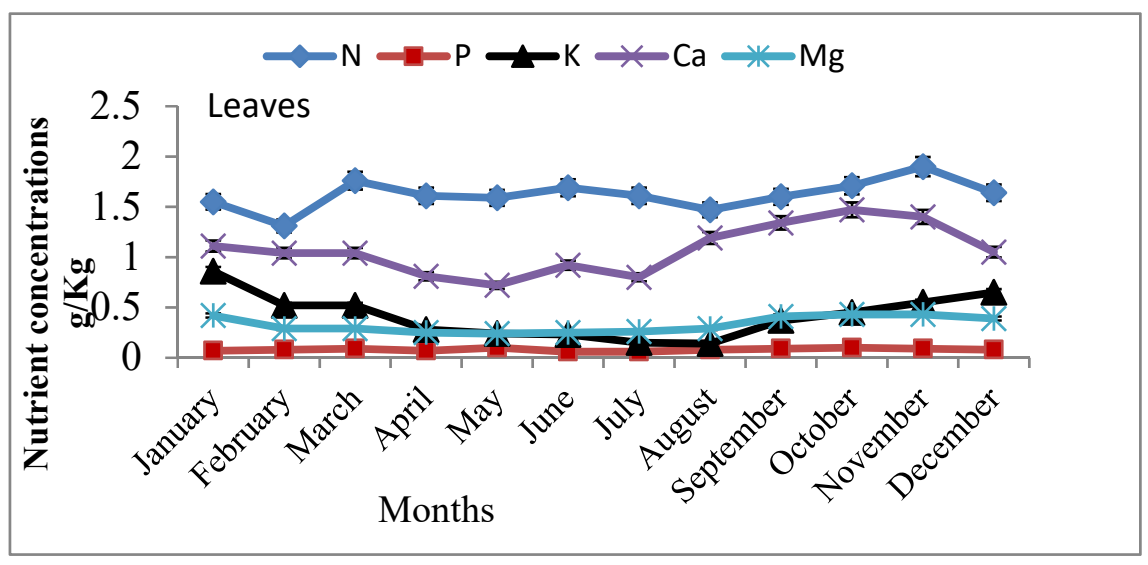

Figure 3. Monthly Variation of Macronutrients Concentrations in leaves

Nitrogen in twigs increased from January to February, and decrease observed from February to June with highest peak in July $(1.28 \mathrm{~g} / \mathrm{kg})$ and November having the least concentration $(0.99 \mathrm{~g} / \mathrm{kg})$.Calcium concentration followed a similar pattern to that of nitrogen but with highest concentration in October $(1.38 \mathrm{~g} / \mathrm{kg})$ and least concentration in December $(0.81 \mathrm{~g} / \mathrm{kg})$.Potassium had a sharp drop from January $(0.77 \mathrm{~g} / \mathrm{kg})$ to a minimum concentration in April $(0.1 \mathrm{~g} / \mathrm{kg})$ with highest peak in December $(0.8 \mathrm{~g} / \mathrm{kg})$. Magnesium and phosphorus had similar patterns where they decreased from peaks of $0.26 \mathrm{~g} / \mathrm{kg}$ and $0.06 \mathrm{~g} / \mathrm{kg}$ respectively in January to the least concentration of $0.23 \mathrm{~g} / \mathrm{kg}$ and $0.04 \mathrm{~g} / \mathrm{kg}$ in April (Figure 4). 


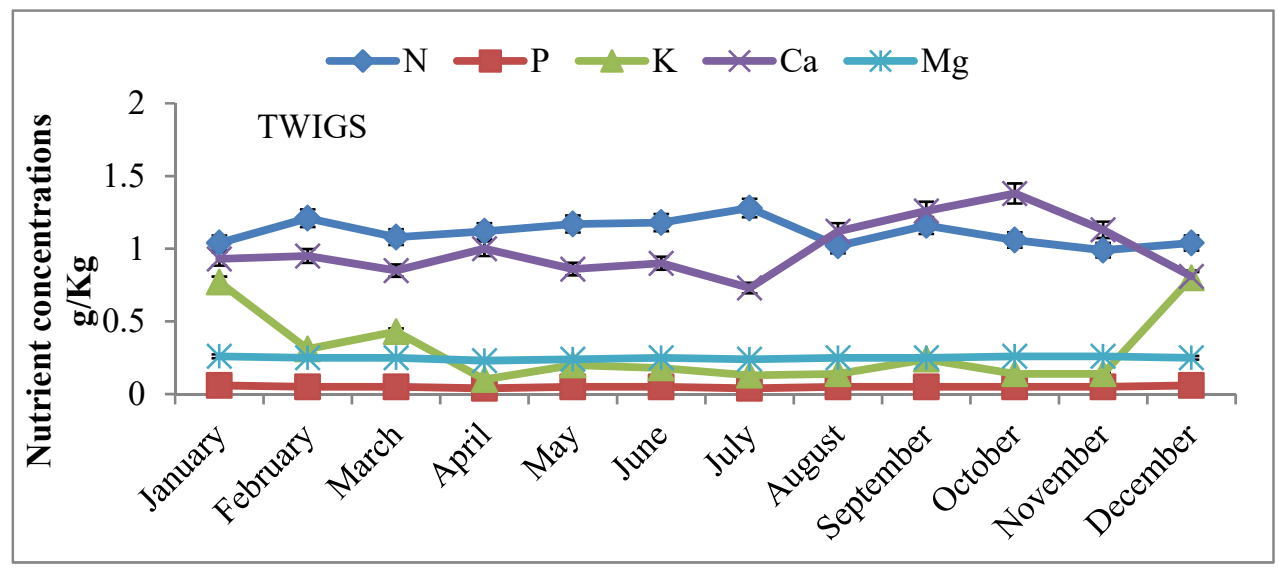

Figure 4. Monthly Variation of Macronutrients Concentrations in twigs

It was observed that concentrations of calcium, magnesium and phosphorus in the reproductive structures were highest in January. The following pattern of nutrient concentration were observed $\mathrm{N}>\mathrm{Ca}>\mathrm{K}>\mathrm{Mg}>\mathrm{P}$. Nitrogen concentration had a decrease from February $(1.72 \mathrm{~g} / \mathrm{kg})$ to April $(1.26 \mathrm{~g} / \mathrm{kg})$ with highest peaks in November and December $(1.92 \mathrm{~g} / \mathrm{kg})$. Potassium had a sharp drop from highest concentrations in January $(0.18 \mathrm{~g} / \mathrm{kg})$ to a minimum in April $(0.05 \mathrm{~g} / \mathrm{kg})$. Calcium decreased from the highest concentration $(0.92 \mathrm{~g} / \mathrm{kg})$ in January to the least concentration $(0.28 \mathrm{~g} / \mathrm{kg})$ in September and October. Phosphorus and magnesium had a similar pattern to that of calcium (Figure 5).

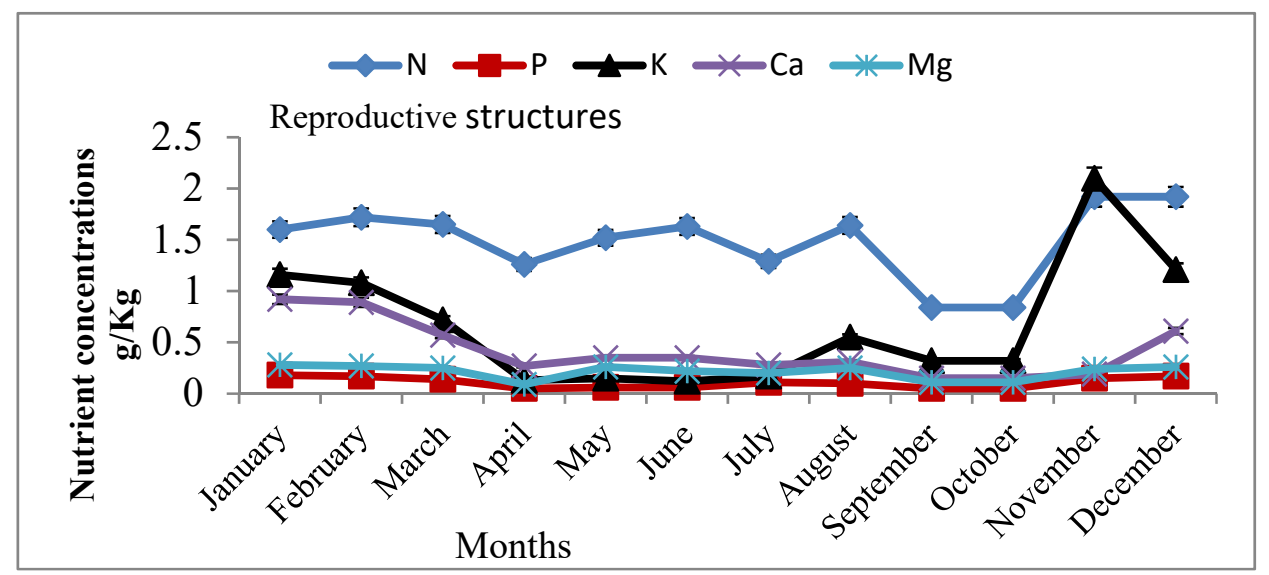

Figure 3. Monthly Variation of Macronutrients Concentrations in reproductive structures

\subsection{Total Annual Litterfall, Biomass and Macronutrients Inputs in the TFDP}

Total annual litterfall was $5.46 \mathrm{t} / \mathrm{ha} / \mathrm{yr}$ during the study period (Table 1). Nitrogen contributed a higher amount of input to the TFDP with the following pattern of nutrients input $\mathrm{N}>\mathrm{Ca}>\mathrm{K}>\mathrm{Mg}>\mathrm{P}(85.36 \mathrm{~kg} / \mathrm{ha} / \mathrm{yr}>56.71 \mathrm{~kg} / \mathrm{ha} / \mathrm{yr}>$ $23.1 \mathrm{~kg} / \mathrm{ha} / \mathrm{yr}>17.32 \mathrm{~kg} / \mathrm{ha} / \mathrm{yr}>4.27 \mathrm{~kg} / \mathrm{ha} / \mathrm{yr}$ ) respectively.

Table 1. Total annual biomass and macronutrients inputs from litterfall in the TFDP

\begin{tabular}{llllllll}
\hline Litter fragment & Biomass (kg/ha/yr) & \% Biomass & $\mathbf{N}(\mathbf{k g} / \mathbf{h a} / \mathbf{y r})$ & $\mathbf{P}(\mathbf{k g} / \mathbf{h a} / \mathbf{y r})$ & $\mathbf{K}(\mathbf{k g} / \mathbf{h a} / \mathbf{y r})$ & $\mathbf{C a}(\mathbf{k g} / \mathbf{h a} / \mathbf{y r})$ & $\mathbf{M g}(\mathbf{k g} / \mathbf{h a} / \mathbf{y r})$ \\
\hline Leaves & 4964.5 & 90.93 & 79.67 & 3.97 & 20.87 & 52.28 & 16.09 \\
Twigs & 426.7 & 7.81 & 4.67 & 0.22 & 1.75 & 4.12 & 1.08 \\
Reproductive parts & 69.04 & 1.26 & 1.02 & 0.08 & 0.48 & 0.31 & 0.15 \\
Total & 5460.3 & 100 & 85.36 & 4.27 & 23.1 & 56.71 & 17.32 \\
\hline
\end{tabular}


In order to qualify the relationship between litterfall and rainfall and between litterfall and temperature, the coefficient of correlation was determined (Table 2). The coefficient of correlation showed a negative value $(-0.56)$ but weak relation with rainfall. However, it correlated positively $(0.03)$ with temperature which was very low.

Table 2. Coefficient of Correlation between litterfall and rainfall and litterfall and temperature of the study site

\begin{tabular}{llll}
\hline & Mean temperature & Rainfall & Total biomass \\
\hline Mean_tempearture & 1 & & \\
Rainfall & 0.04 & 1 & \\
Total biomass & 0.03 & $-0.56^{*}$ & 1 \\
\hline
\end{tabular}

\subsection{Nutrients Retranslocation by Some Three Key Tree Species}

The concentration of $\mathrm{N}, \mathrm{K}$ and $\mathrm{P}$ in mature green leaves was observed to be higher than that of fallen brown leaves in all three-tree species. The concentrations of $\mathrm{Mg}$ and $\mathrm{Ca}$ were higher in fallen brown leaves than in mature green leaves. Percentage retranslocation of $\mathrm{N}$ and $\mathrm{P}$ was significantly higher in Afzeliabipidensis and Pterocarpus soyauxii but low in Terminalia ivorensis. Percentage retranslocation of calcium was observed to be constant $(0 \%)$ for all the three species because it was on Ca basis that retranslocation values were computed.

\section{Discussion}

The annual litterfall of this study site was $5.46 \mathrm{t} /$ ha /year with the highest peak in February.Litterfall exhibited a clear pattern with very conspicuous peaks in the dry seasons and this corroborated the findings of Chuyong et al. (2000). However, it was inconsistent with the findings of Songwe et al. (1988) in the Southern Bakundu rainforest where they had 12.9t/ha/yr and 14.1t/ha/yr. According to Hermansah et al. (2002), litterfall in the Indonesian tropical rainforest was $11.7 \mathrm{t} / \mathrm{ha} /$ year with highest production occurring in June, this was comparably higher than that of the TFDP.These peaks occurred in the heart of the dry season when there are high temperatures, which might cause a decrease in soil moisture, low humidity with shedding senesced dry leaves, to reduce evapotranspiration. However, it was within the range of Yang et al. (2004) whose values ranged from $4.63 \mathrm{t} / \mathrm{ha} /$ year to $8.85 \mathrm{t} / \mathrm{ha} /$ year but lower as compared to that of tropical forest in Ghana (10.7 t/ha) and Ivory coast-Yapo and Banco $11.9 \mathrm{t} / \mathrm{ha}$ and $9.6 \mathrm{t} / \mathrm{ha}$ respectively (Vitousek and Sandford, 1986), and 7.1 t/ha to 8.7 t/ha Egbe et al. (2003). This low annual litter production might have occurred because this forest is an evergreen rainforest which illustrates that the species exhibited less leaf shed as compared to those of other forests. Also it might have been influenced by the rainfall pattern of this area as there are rains up to December.

The proportion of leaf litter of the three components of litterfall was $90.9 \%$ comparably higher than that of other tropical rainforests in Brazil (54.6 \%) (White et al., 2013). This may be due to increased plant demand for water, dispensing leaves during the dry season as a strategy aimed at reducing water requirements during a period of water deficit (Barbosa \& Faria, 2006).Leaves may also be shed due to physical damage (Onoda et al., 2011). These factors may also cause disorder in cellular activity and thus induce senescence, although it can also be induced by natural variation in hormone levels over the plants life cycle (Munne-Bosh \& Alecre, 2004).

Twigs corresponded to $7.8 \%$ of total litterfall with significant monthly variation and peak in January.This was inconsistent with the findings of Valenti et al. (2007) and White et al. (2013) who had 31\% with peaks in April.During the dry seasons plants shed their leaves as an adaptive function to drought stress and some tree species also shed their branches in this respect.

Reproductive parts corresponded to $1.2 \%$ of total litterfall, which was consistent with the findings of Dent et al. (2006) who observed that reproductive structures constituted $1 \%$ of litter fall. However, this was lower than that of Scheer et al. (2009) in the southern Brazil rainforests (4\%). The discrepancies in the results may be because some plants only fruit after a long period for example some stay for about three to four years before flowering or fruiting, but this research was carried out for a year.

The macronutrient concentrations in leaf litter showed that $\mathrm{N}$ and $\mathrm{Ca}$ were the major elements with higher concentrations in litterfall. This corroborated the findings of Bhat and Jan (2010). It has been shown that Ca is immobile in the plant vascular system and is believed to be recycled by means of litter decomposition. In addition, calcium is present in plant tissues in the form of calcium ions or insoluble salts in the vacuoles. It is bound as calcium pectates in the cell walls. This suggests that calcium may have less leaching characteristics compared with other nutrients (Vitousek, 1984). Leaves are areas of active biochemical activities and nitrogen is 
needed for amino acid and protein synthesis; this may be the reason for higher nitrogen concentrations in leaves compared twigs and reproductive structures (Killingbeck, 1996).

The quantity of macronutrients returned to the forest floor is an important factor in the succession stages of soil organic carbon resulting in higher availability of nutrients in these compartments. The amount of nutrients inputs in this study site was comparably higher than that of tropical rainforests of Indonesia as reported by Hermansah et al. (2002) (N $92 \mathrm{~kg} / \mathrm{ha}, \mathrm{K} 17 \mathrm{~kg} / \mathrm{ha}, \mathrm{Ca} 9 \mathrm{~kg} / \mathrm{ha}, \mathrm{P} 3 \mathrm{~kg} / \mathrm{ha}, \mathrm{Mg} 1 \mathrm{~kg} / \mathrm{ha})$ and Dachigam National Park (Ca $53.16 \mathrm{~kg} / \mathrm{ha}, \mathrm{Mg} 10.59 \mathrm{~kg} / \mathrm{ha}, \mathrm{N} 47.78 \mathrm{~kg} / \mathrm{ha}, \mathrm{P} 9.70 \mathrm{~kg} / \mathrm{ha}, \mathrm{K} 21.25 \mathrm{~kg} / \mathrm{ha}$ ) respectively (Bhat \& Jan, 2010). However, the P input was similar to inputs in the Brazilian and Ivory Coast forests (Vitousek \& Sandford, 1986). This variation is due to differences in concentration of these nutrients in litterfall. The higher the concentration the higher is the return of nutrient through litterfall (Bhat \& Jan, 2010).

\section{Conclusion}

From the findings of this study it could be deduced that Litterfall and nutrient input are low in the Takamanda forest dynamic plot. Leaf litter constitutes the greatest part of litterfall and had the highest nutrient concentrations of all litterfall fragments. Nutrient input from leaf litter was highest as compared to other litter fractions. There was also seasonal variation in litter nutrients concentration with peaks in the dry season as compared to the rainy seasons, where some of the nutrients may be leached. Furthermore, litterfall contributes high amounts of nutrients returned to the soil with highest contributions coming from leaf litter. A greater percentage of nutrients are reabsorbed to the plant before leaf fall, but calcium and magnesium tend to accumulate in the litterfall. Terminalia ivorensisis a good nutrient recycler and should thus be used to improve on degraded soils. While Afzeliabipidensis and Pterocarpus soyauxii are good internal recyclers that can establish easily on nutrient-poor soils. Thus, in light with forest productivity, trees like Pterocarpus soyauxii and Afzeliabipidensis should be planted more in forests especially in tropical rainforests which are known to be characterized by nutrient-poor soils. Also, trees like Terminalia ivorensis are encouraged to be planted in other tropical rainforest and other areas with nutrient-poor soils so as to improve on their nutrient-poor soils thus improving on forest productivity.

\section{References}

Anderson, J. M., \& Ingram, J.S.I. (1993). Tropical soil biology and fertility: a handbook of methods (2nd ed.). Aberstwyth: CAB International.

Barbosa, J. H. C., \& de Faria, S. M. (2006). Aporte de serrapilheiraao solo emestágios sucessionais florestaisna Reserva Biológica de Poço das Antas, Rio de Janeiro, Brasil. Rodriguésia, 461-476.

Benton J.J., \& Vernon, W. C. (1990). Sampling, handling and analyzing plant tissue samples. In R. L. Westerman (Ed.), Soil testing and plant analysis (3rd ed., pp. 389-427). SSSA Book Series.

Bergamini Scheer, M., Gatti, G., \& Wisniewski, C. (2011). Nutrient fluxes in litterfall of a secondary successional alluvial rain forest in Southern Brazil. Revista de biologia tropical, 59(4), 1869-1882.

Bhat, N. H., \& Jan, S. (2010). Litterfall and nutrient return in Ulmusvillosa forests of Dachigam National Park, Jammu and Kashmir. Res J Agric Sci, 1(4), 363-365.

Bigelow, S. W., \&Canham, C. D. (2015). Litterfall as a niche construction process in a northern hardwood forest. Ecosphere, 6(7), 1-14.

Buondonno, A., Rashad, A. A., \& Coppola, E. (1995). Comparing tests for soil fertility. II. The hydrogen peroxide/sulfuric acid treatment as an alternative to the copper/selenium catalyzed digestion process for routine determination of soil nitrogen kjeldahl. Communications in soil science and plant analysis, 26(9-10), 1607-1619.

Chuyong, G. B., Newbery, D. M., \& Songwe, N. C. (2000). Litter nutrients and retranslocation in a central African rain forest dominated by ectomycorrhizal trees. New Phytologist, 148(3), 493-510.

Dam, O. V. (2001). Forest filled with gaps: effects of gap size on water and nutrient cycling in tropical rain forest: a study in Guyana (Doctoral dissertation).

Dent, D. H., Bagchi, R., Robinson, D., Majalap-Lee, N., \&Burslem, D. F. (2006). Nutrient fluxes via litterfall and leaf litter decomposition vary across a gradient of soil nutrient supply in a lowland tropical rain forest. Plant and Soil, 288(1-2), 197-215. 
Egbe, E., Swift, M., Nwoboshi, L., \& Ladipo, D. (2003). Litter fall and macronutrients return of Millettiathonningii [Schumach and V Thonn.] Bak and Pterocarpus santalinoides [L' Herite, ex Dc.] stands in south-western Nigeria. Journal of the Cameroon Academy of Sciences, 3(2), 87-94.

Eguakun, F. S., \& Job, M. (2018). Statistical relationship between leaf litter and tree growth characteristics of Tectonagrandis species. World News of Natural Sciences, 18(2), 252-261.

Hermansah, A. Z., Tsugiyuki, M., \& Toshiyuki,W. (2002). Litterfall and nutrient flux in tropical rainforest.West Sumatra, Indonesia: Symposium paper, 1125, 14-17.

Higuera, D., \& Martinez, E. (2006). Litterfall and nutrient fluxes in canopy oaks in neotropical cloud forest. Colombia Journal of Ecology and Application, 11(1), 67-74.

Killingbeck, K.T. (1996). Nutrients in senensced leaves: keys to the search for potential resorption and resorption efficiency. Ecology, 77, 1716-1727.

Lidman, J., Jonsson, M., Burrows, R. M., Bundschuh, M., \& Sponseller, R. A. (2017). Composition of riparian litter input regulates organic matter decomposition: Implications for headwater stream functioning in a managed forest landscape. Ecology and evolution, 7(4), 1068-1077.

Londe, V., De Sousa, H. C., \& Kozovits, A. R. (2016). Litterfall as an indicator of productivity and recovery of ecological functions in a rehabilitated riparian forest at Das Velhas River, southeast Brazil. Tropical Ecology, 57(2), 355-360.

Munné-Bosh, S.,\& Alegre, L. D. (2004). Leaf senescence contributes to plant survival under drought stress. Functional Plant Biology, 31(1), 203-216.

Onoda, Y., Westoby, M., Adler, P. B., Choong, A. M., Clissold, F. J., Cornelissen, J. H., ... \& Fine, P. V. (2011). Global patterns of leaf mechanical properties. Ecology letters, 14(3), 301-312.

Regina, M., Wetrington, B. D.,\& VanaStru, F. F. A. D. V. (1999). Litter and nutrient content in two Brazilian tropical Forest. Journal of Brasilian Botany, 22.

Sizer, N. C., Tanner, E. V., \& Ferraz, I. D. K. (2000). Edge effects on litterfall mass and nutrient concentrations in forest fragments in central Amazonia. Journal of Tropical Ecology, 16(6), 853-863.

Songwe, N. C., Fasehun, F. E., \& Okali, D. U. U. (1988). Litterfall and productivity in a tropical rain forest, Southern Baakundu Forest Reserve, Cameroon. Journal of Tropical Ecology, 4(1), 25-37.

Valenti, M. W., Cianciaruso, M. V., \& Batalha, M. A. (2008). Seasonality of litterfall and leaf decomposition in a cerrado site. Brazilian journal of Biology, 68(3), 459-465.

Vitousek, P. M., \& Sanford Jr, R. L. (1986). Nutrient cycling in moist tropical forest. Annual review of Ecology and Systematics, 17(1), 137-167.

Vitousek, P. M., Gerrish, G., Turner, D. R., Walker, L. R., \& Mueller-Dombois, D. (1995). Litterfall and nutrient cycling in four Hawaiian montane rainforests. Journal of Tropical Ecology, 11(2), 189-203.

Wang, J., Xu, B., Wu, Y., Gao, J., \& Shi, F. (2016). Flower litters of alpine plants affect soil nitrogen and phosphorus rapidly in the eastern Tibetan Plateau. Biogeosciences, 13(19), 5619.

White, B. L. A., Nascimento, D. L. D., Dantas, T. V. P., \& Ribeiro, A. D. S. (2013). Dynamics of the production and decomposition of litterfall in a Brazilian northeastern tropical forest (Serra de Itabaiana National Park, Sergipe State). Acta Scientiarum. Biological Sciences, 35(2), 195-201.

Yang, Y. S., Guo, J. F., Chen, G. S., Xie, J. S., Cai, L. P., \& Lin, P. (2004). Litterfall, nutrient return, and leaf-litter decomposition in four plantations compared with a natural forest in subtropical China. Annals of Forest Science, 61(5), 465-476.

\section{Copyrights}

Copyright for this article is retained by the author(s), with first publication rights granted to the journal.

This is an open-access article distributed under the terms and conditions of the Creative Commons Attribution license(http://creativecommons.org/licenses/by/4.0/). 